\title{
Digital Innovation: Creating Competitive Advantages
}

\author{
Mohammed Ali Berawi ${ }^{*}$, Nyoman Suwartha1, Muhamad Asvial², Ruki Harwahyu², \\ Muhammad Suryanegara ${ }^{2}$, Eko Adhi Setiawan², Isti Surjandari', Teuku Yuri M. Zagloel ${ }^{3}$, \\ Imam Jauhari Maknun ${ }^{1}$ \\ ${ }^{1}$ Department of Civil Engineering, Faculty of Engineering, Universitas Indonesia, Kampus UI Depok, \\ Depok 16424, Indonesia \\ ${ }^{2}$ Department of Electrical Engineering, Faculty of Engineering, Universitas Indonesia, Kampus UI Depok, \\ Depok 16424, Indonesia \\ ${ }^{3}$ Department of Industrial Engineering, Faculty of Engineering, Universitas Indonesia, Kampus UI Depok, \\ Depok 16424, Indonesia
}

The diffusion of innovations during the fourth industrial revolution reshaped economic systems and caused structural changes in different economic sectors. These innovations have become the basis of the new digital infrastructure of society.

Digital technology is used to manage integrated product whole-life cycles and enhance efficient, reliable, and sustainable business operations. Intelligent production processes and supply chains can be used to optimize entire end-to-end workflows and create business competitive advantages. Artificial intelligence, internet of things, machine learning, blockchain, big data and other digital technologies have been used to create business agility and resilience and further transform societal behavior.

Digitalization creates new ways for companies to create business added value. Modernizing business enterprises by combining digital technologies, physical resources, and the creativity of individuals, is an essential step in innovative business transformation that may constitute a competitive advantage.

Companies need to transform their business processes and enhance the satisfaction of their customers by using digital technologies that connect people, systems, and products or render their services more effective and efficient. Digital technologies create new ways for companies to integrate customers' requirements into product development or service delivery across entire process chains.

Digital technologies are becoming increasingly important due to strong market competition. Many studies have shown that there is a strong correlation between business growth and the use of digital technologies to create innovative business models. Technological innovations create new products, processes, and services that generate more added value for companies.

\section{Digital Innovation Ecosystems}

Ecosystems for digital innovations are necessary to create a system that supports digital technology deployment. These ecosystems require an enhancement of institutional policies, digital actors, and technology development. 
Digital transformation policies are essential in creating ecosystems for digital growth strategies. The ecosystems should be boosted by supportive policy design, adequate funding, and program implementation. The transformation policies must provide adequate technology infrastructure and development of skills.

Digital transformation offers new emerging economic models such as sharing and circular economy. The exploitation of digital tools is expected to reduce the operational costs of businesses by increasing flexibility, reducing waste, and enabling companies to transform into lean and efficient organizations.

Many industries, from product manufacturing to construction and business services industries, are now extensively using digital technologies. There is an increased amount of investments on technological products and applications to enhance industrial performance, achieve efficiency, and offer new and extended markets-in other words, the digital economy ecosystem is being created.

This special issue is dedicated to discussing the progress of digital innovation by promoting collaboration to provide innovative solutions. The papers are selected from the SPBPU IDE-2020 conference that was held on October 2020 and co-organized by the Graduate school of Industrial Economics (GSIE) at Peter the Great Saint Petersburg Polytechnic University (SPbPU) along with the Faculty of Engineering Universitas Indonesia, Center for Sustainable Infrastructure Development (CSID) of Universitas Indonesia (UI). The topics of the conference ranged from economic efficiency and social consequences of the implementation of digital innovations to digital transformation in the government and in the financial and various industrial sectors. In this edition, we are pleased to present 19 papers on digital innovation.

The first paper, written by E. Rytova, T. Verevka, S. Gutman, and S. Kuznetsov, assesses the maturity level of Saint Petersburg's digital government. The authors' recommendations for architectural transformation include the reengineering of administrative processes and the utilization of national databases, digital services among government bodies, and digital governmental platforms to allow direct interaction with citizens and businesses.

The next paper, written by A. Skhvediani and S. Sosnovskikh, discusses the importance of agglomeration externalities that may impact the development of innovation and the high technology sector in regional economies. The authors argue that the concentration of high levels of employment, sales volumes, and paid wages in the electrical equipment, electronic, and optical equipment sectors are related to hi-tech usage density.

The third paper, written by K. Sarachuk and M. Mißler-Behr, examines the impact of ultra-broadband provision on firm creation at a municipal level in Germany. The authors argue that digital policies should incorporate additional aspects, such as the improvement of technological skills or the fostering of an entrepreneurial spirit, and not solely focus on the development of digital infrastructure.

The fourth paper, written by T. Golovina, A. Polyanin, A. Adamenko, E. Khegay, and V. Schepinin, investigates the core principles and the possibility of using digital twin technology for the development of Russia's industrial sectors. According to the authors, the use of digital twin technology as a modern production infrastructure increases the volume of production of high tech and science-intensive products that can adapt to current market needs.

The fifth paper, written by B. Onykiy, E. Antonov, A. Artamonov, and E. Tretyakov, presents the development of an informational and analytical system to foster scientific and technological development. The authors posit that the system is scalable and can be used to improve performance, reduce workflow execution time, and enhance the capacity of workers. 
The next paper, written by L. Mazelis, K. Lavrenyuk, and A. Krasko, presents a method of creating the optimal portfolio of strategic projects to maximize regional development. It is noted that a higher efficiency of financial resources creates a higher chance of achieving the integrated targets of social and economic development for the regional project portfolio.

The seventh paper, written by A. Polyanin, L. Pronyaeva, D. Rodionov, A. Pavlova, and O. Fedotenkova, proposes an integrated approach to the assessment of the economic security of a cluster. The authors argue that the proposed methodology for assessing the economic security of a cluster comprises of a comprehensive approach to considering all the possible risks and threats in the functioning of the individual components of the cluster's structure.

In the eighth paper, written by E. Kozonogova, J. Dubrovskaya, and Y. Dubolazova, a quantitative assessment of the role of interregional interaction in the Russian economy is presented. The authors argue that the interaction of economic entities is important for the system of interregional relations to function effectively, ensuring the development of the country.

The next paper by E. Koshelev, S. Yashin, N. Yashina, O. Kashina, and N.P. Rubtsova, proposes a model of foresight for the innovation system development of federal districts based on the use of a multi-objective genetic algorithm. According to the authors, the model creates synergistic effects for the regions where clusters are located and elucidates more scientific-based regional cluster policies.

The tenth paper, written by E. Koroleva and A. Kuratova, examines the association between the digitalization of the economy and the quality of higher education. The authors note that economic digitalization increases the competitive advantage of the region in terms of education and contributes an important role in regional sustainable development.

The eleventh paper, written by J. Varlamova and N. Larionova, examines the role of information and communication technologies (ICT) in labor productivity dynamics. The authors argue that digitalization of business processes leads to an increase in labor productivity and that certain socioeconomic indicators significantly affect labor productivity in the form of real wages and the percentage of people with higher education in the workforce.

The next paper, written by V.F. Minakov, O.S. Lobanov, and S.A. Dyatlov, examines the three-dimensional trends superposition in the digital innovation life cycle model. The authors argue that the model increases the efficiency of digital innovation management regardless of the type of digital innovative product.

The thirteenth paper, written by I. Rudskaya, I. Ozhgikhin, and D. Kryzhko, proposes a forecasting model to devise a set of the most promising research areas in medical hardware development. The diagnosis of viral infections and investigating the spread of viral infections, coronaviruses, cardiovascular diseases, and lung diseases comprise the most promising research areas.

The fourteenth paper, written by S. Grishunin, S. Suloeva, A. Egorova, and E. Burova, compares the predictive power of various methods of reproducing the public credit ratings (PCRs) of manufacturing companies from available financial and nonfinancial data. The authors argue that comparative results from machine learning techniques compared to traditional methods, are more effective in reproducing the PCRs of manufacturing companies.

The next paper, written by L.I. Nickolaevich, G.I. Igorevna, and R.D. Grigorievich, examines a multi-timeframe trading strategy based on three exponential moving averages and a stochastic oscillator. The authors argue that the trading algorithm can be programmed for automated trading systems and developed into a robo-advisor. 
The sixteenth paper, written by I. Lyukevich, A. Agranov, N. Lvova, and L. Guzikova, presents a classification of the tools for evaluating business economic risk and the process of selecting appropriate methods for assessing risk events based on available information. The authors point out that the risk model includes an assessment not only when there is accessible and relatively transparent information, but also in the presence of significant information asymmetry.

The next paper, written by N. Victorova, E. Rytova, L. Koroleva, and N. Pokrovskaia, analyzes the relationship between tax share and the investment attractiveness and innovative activity of the territory. As noted in the paper, the tax capacity of the federal districts is determined by the macroeconomic indicators that affect the size of the tax base of budget-generating taxes and that the tax capacity differs significantly across federal districts.

The eighteenth paper, written by H. Fathurahman, M.A. Berawi, I. Sulistyarini, A. Kusuma, Y. Nasution, and Komarudin, recommends post-COVID-19 recovery models and strategies for the aviation industry. The authors determined that several scenarios and business models, classified as optimistic, moderate, and conservative are necessary for the recovery of the industry.

The last paper, written by A. Bencsik, posits that business strategies can be determined in the digital economy. According to the author, even when companies have prepared business strategies, the deficiencies of organizational culture pose the main obstacle to achieving corporate success.

We hope that this edition of IJTech conveys some new insights into the way we conduct our research. We are pleased to accept and respond to any comment or enquiry you may have on the mission and content of IJTech, and we invite you to join us on this venture by sending your work to us for consideration.

With warmest regards from Jakarta,

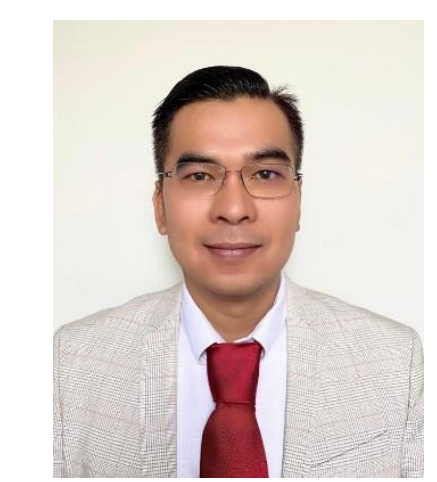

Dr. Mohammed Ali Berawi Editor in Chief

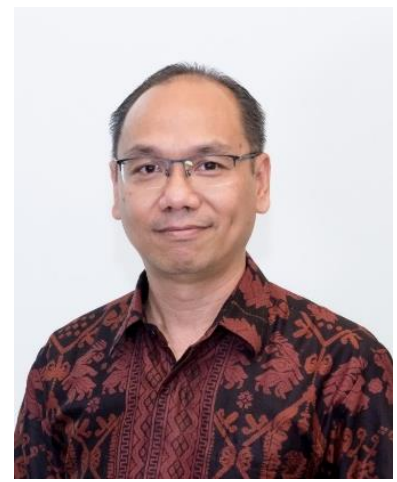

Dr. Nyoman Suwartha Managing Editor

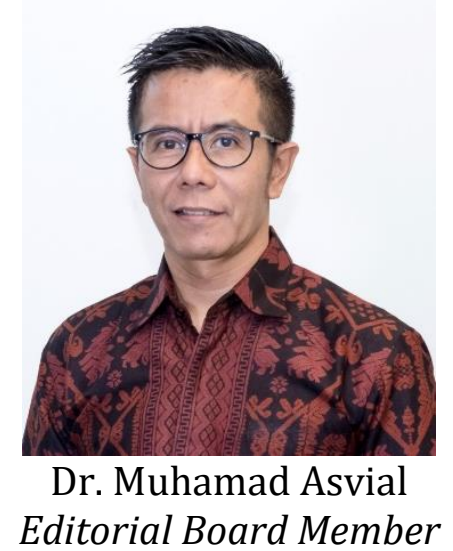




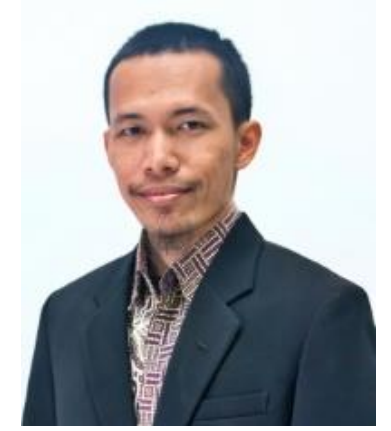

Dr. Ruki Harwahyu Editorial Board Member

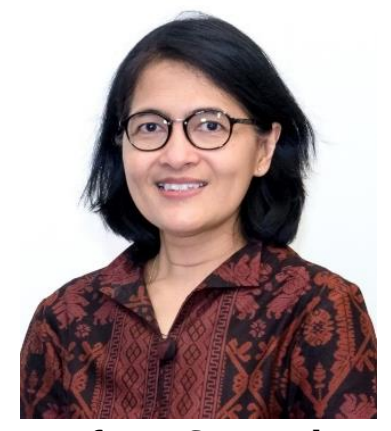

Prof. Isti Surjandari Editorial Board Member

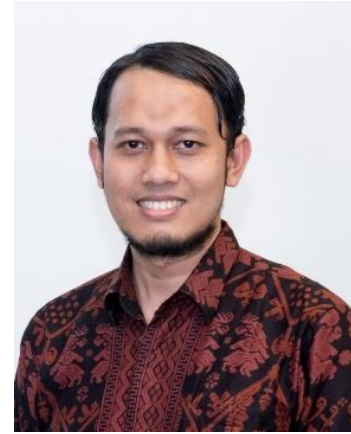

Dr. Muhammad Suryanegara Editorial Board Member

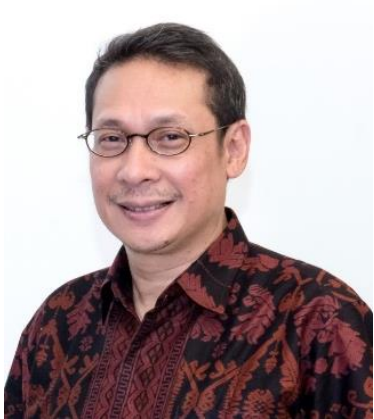

Prof. Teuku Yuri M. Zagloel Editorial Board Member

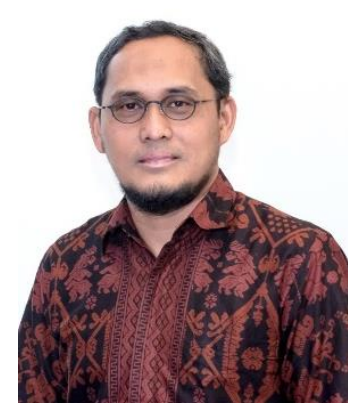

Dr. Eko Adhi Setiawan Editorial Board Member

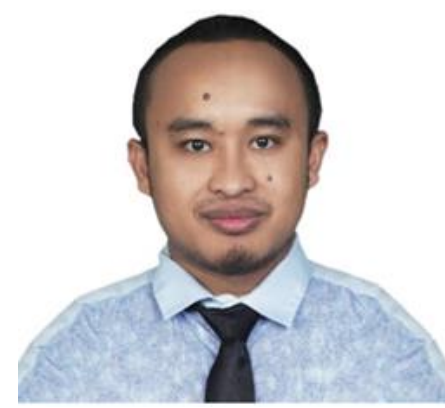

Dr. Imam Jauhari Maknun Editorial Board Member 